\title{
Age determination of archer fishes (Toxotes jaculatrix and Toxotes chatareus) inhabiting Malaysian estuaries
}

\begin{abstract}
In this study the most common bony structure (scales) and method was investigated for age determination of archer fishes. A total of 85 specimens of archer fishes (Toxotes chatareus and Toxotes jaculatrix) from the estuaries of South Johore, Malaysia were examined for age. Scale length is linearly proportion $(\mathrm{r}=0.816)$ to standard length $(\mathrm{SL})$. Relationship between scale length (L) and scale weight (W) can be expressed by the formula $\mathrm{W}=0.0155 \mathrm{~L} 2.917$. Daily growth rings and annulus of scales count up demonstrated that the ages of the samples for both species were mostly 1-2 years and a handful samples of T. jaculatrix were above 2 years.
\end{abstract}

Keyword: Archer fish; Toxotes chatareus; Toxotes jaculatrix; Daily growth rings; Scale 